\title{
Monuments of Ruination in Postwar Berlin and Warsaw: The Architectural Projects of Bohdan Lachert and Daniel Libeskind
}

\author{
MICHAEL MENG \\ History, Clemson University
}

Accourez, contemplez ces ruines affreuses.

The ruin has long been viewed as a remnant of a lost vitality or wholeness that prompts either forgetting or nostalgia - reactions that avoid confronting the ruin for what it is as a site of impermanency and fragility, of suffering and death, as Voltaire insisted in the wake of the Lisbon earthquake of 1755. Whether the source of ruination might be described as natural or historic, whether the process of destruction might have unfolded slowly or erupted suddenly, the ruin stands as a memento mori that reveals the vulnerability of human creations no matter how monumental they might be: the elegant, imperial city of Lisbon was rendered into a chaotic site of crashing waves, crumbling stone, and smoke-filled skies in a matter of seconds. "The earthquake of Lisbon sufficed to cure Voltaire of the theodicy of Leibniz," Theodor W. Adorno wrote nearly two centuries later, ${ }^{1}$ which is to say that the city's ruination undermined the Enlightenment's exuberant aspiration to yoke nature under human control. Equally, if not more destructive to Enlightenment optimism was the ruination produced by Hitler's genocidal campaign against the Jews, a ruination

\footnotetext{
Acknowledgments: This essay originated from a stimulating conference on absence in modern European history held at the Monash University campus in Prato, Italy. I thank Julie Kalman for kindly inviting me to that conference. I also thank the CSSH editors for soliciting reports from excellent anonymous readers who provided exceptionally thoughtful comments on earlier drafts of this article. Finally, my thanks to David Akin for his careful editing of this essay and seeing it through the publication process. 361 .

1 Theodor W. Adorno, Negative Dialectics, E. B. Ashton, trans. (New York: Routledge, 1973),
} 


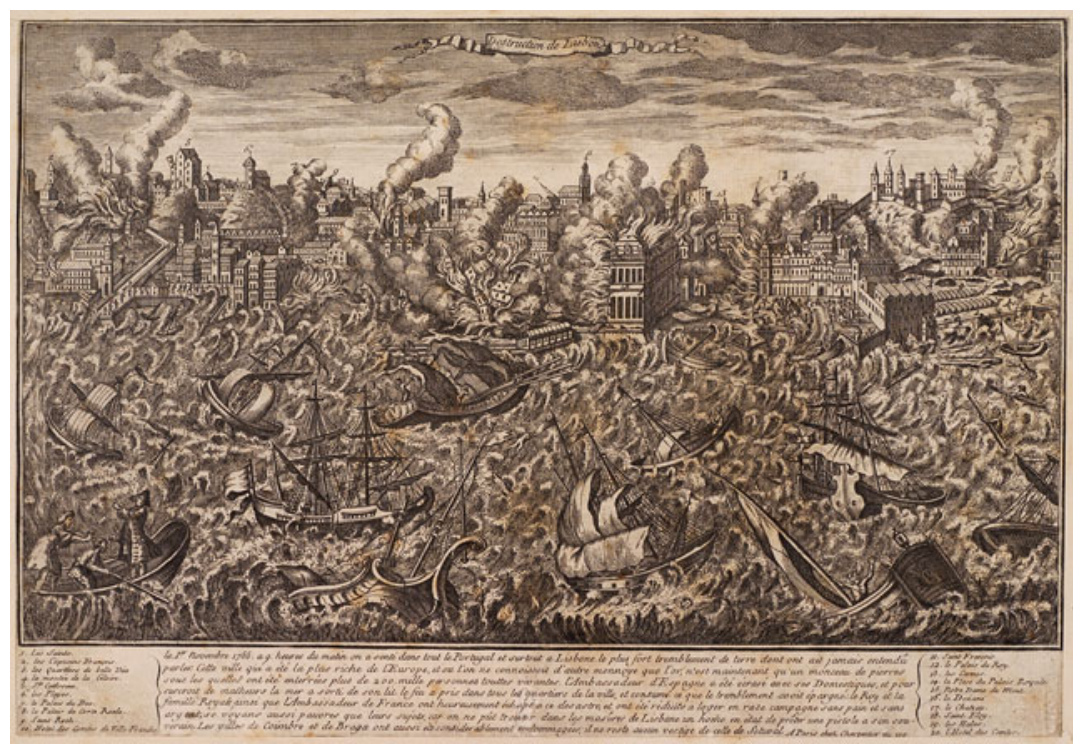

FIgURE 1 A 1775 copper engraving of Lisbon. Courtesy of Museu de Lisboa.

which, as Adorno famously argued with Max Horkheimer, emerged partly from the Enlightenment's striving to master nature. ${ }^{2}$

After 1945, Europeans responded to the ruination produced by Nazism in various ways. In the early postwar years, the prevailing response was to turn away from the death caused by the Holocaust, to clear away and forget Jewish ruins amidst the fervent embrace of urban modernism and optimistic notions of progress. ${ }^{3}$ Traveling across West and East Germany in the early 1960s, Amos Elon wrote, "The resurrected cities-brand new, clean, sober, infinitely monotonous - stand on the former ruins." 4 And yet, as ascendant

${ }^{2}$ Max Horkheimer and Theodor W. Adorno, Dialetic of Enligtenment: Philosophical Fragments, Gunzelin Schmid Noerr, ed., Edmund Jephcott, trans. (Stanford: Stanford University Press, 2002). A thoughtful account that links the ruination of Lisbon with the ruination of the Holocaust in the context of philosophical reactions to evil can be found in Susan Neiman, Evil in Modern Thought: An Alternative History (Princeton: Princeton University Press, 2002). A stimulating set of essays on ruins can be found in Julia Hell and Andreas Schönle, eds., Ruins of Modernity (Durham: Duke University Press, 2010).

${ }^{3}$ Qualification is in order here. See the excellent studies on the complex interaction between modernism and historic preservation in Rudy Koshar, Germany's Transient Pasts: Preservation and National Memory in the Twentieth Century (Chapel Hill: University of North Carolina Press, 1998); and Gavriel Rosenfeld, Munich and Memory: Architecture, Memory, and the Legacy of the Nazi Past (Berkeley: University of California Press, 2000).

4 Amos Elon, Journey through a Haunted Land: The New Germany (New York: Holt, Rinehart, and Winston, 1967), 13. 
as this modernist impulse to bury past ruins was after 1945, it came into question by the late 1970s, when urban modernism was critiqued as ruinous to the historical character and particularity of the city. ${ }^{5}$ Stimulated partly by these critiques, interest in the few Jewish ruins that still could be found began to emerge across parts of the European continent. This interest varied widely from nostalgic efforts to "recover" the prewar Jewish past to searing efforts to reflect on the death and destruction of the Holocaust.

In this essay, I would like to discuss this shifting history of encounters with Jewish ruins by focusing first on the early postwar forgetting of Jewish ruins during the height of urban modernism, and then on efforts since the late 1970 s to reflect on the ruination of prewar Jewish life. To sharpen my focus, I will examine two examples from Central Europe that I consider to be paradigmatic of each respective historical period: the attempt by architect Bohdan Lachert to memorialize the ruins of the Warsaw ghetto in the early 1950s and that by Daniel Libeskind in the late 1980s to create a metaphorical ruin in Berlin so as to express the death and destruction of the Holocaust. What unites these two temporally and spatially different examples is the intention of both artists to reflect on death, suffering, and absence.

Lachert's Warsaw project has received relatively little scholarly attention, while Libeskind's Berlin project has received so much that readers may reasonably wonder if there is anything new to say about it. ${ }^{6}$ Yet one aspect of Libeskind's project deserves more attention than it has gotten, namely the ambition and ambiguity of Libeskind's effort to create a building of fragments that fail to come together into a whole. ${ }^{7} \mathrm{He}$ sought to create a monument of ruination that resists the modernist impulse to turn away from suffering and destruction. He

\footnotetext{
5 Christopher Klemek, The Transatlantic Collapse of Urban Renewal: Postwar Urbanism from New York to Berlin (Chicago: University of Chicago Press, 2011).

6 The main studies of Muranów are: David Ira Snyder, "The Jewish Question and the Modern Metropolis: Urban Renewal in Prague and Warsaw, 1885-1950," (PhD diss., Princeton University, 2006); Michael Meng, Shattered Spaces: Encountering Jewish Ruins in Postwar Germany and Poland (Cambridge: Harvard University Press, 2011); and Beata Chomątowska, Stacja Muranów (Wołowiec: Wydawnictwo Czarne, 2012). On the history of Libeskind's project, see Paul B. Jaskot, "Daniel Libeskind's Jewish Museum in Berlin as a Cold War Project," in Philip Broadbent and Sabine Hake, eds., Berlin: Divided City, 1945-1989 (New York: Berghahn Books, 2010); Kartin Pieper, Die Musealisierung des Holocaust: Das Jüdische Museum Berlin und das U.S. Holocaust Memorial Museum in Washington D.C. (Cologne: Böhlau, 2006); and Caroline Wiedmer, The Claims of Memory: Representations of the Holocaust in Contemporary Germany and France (Ithaca: Cornell University Press, 1999); 145-55. For architectural discussions and appreciations of Libeskind's project, see Andreas Huyssen, "Voids of Berlin," Critical Inquiry 24, 1 (1997): 57-81; and James Young, At Memory's Edge: After-Images of the Holocaust in Contemporary Art and Architecture (New Haven: Yale University Press, 2000), 152-83. For an excellent contextualization of Jewish architecture after the Holocaust, see Gavriel D. Rosenfeld, Building after Auschwitz: Jewish Architecture and the Memory of the Holocaust (New Haven: Yale University Press, 2011).

7 The main work that deals with the theoretical question that interests me is Jacques Derrida's "Response to Daniel Libeskind," Research in Phenomenology 22, 1 (1992): 88-94. To be sure, there is a body of literature that deals with questions related to mine concerning Holocaust
} 
wanted to create a ruinna - Latin for "collapse" - in a fully constructed building designed to tell a historical narrative that, as such, is inherently holistic. ${ }^{8}$ This is a project of considerable tension that prompts several questions: Is this effort coherent? How can a new building represent ruination and absence? And how, in the particular case of Libeskind's project, does the building's purpose as a history museum match its architectural attempt to represent what has been lost? How does the museum's historical narrative of continuity match his interest in expressing rupture? In raising these questions, my purpose is not to cast doubt on the "success" of Libeskind's project, but rather to explore the challenge he faced in striving to represent absence within the context of his building's pedagogical, historical purpose.

In the end, the two examples discussed here, while coming from different historical contexts, suggest two striking affinities that transcend their otherwise obvious differences. The first may be expressed in terms of a tension that courses through both cases: between revealing and concealing the ruin as a site of suffering, death, and absence. The concealing side of this dyad may initially seem most overt in the case of Warsaw, where the history of the ghetto was forgotten almost entirely with the construction of new buildings on top of it in the early 1950s. ${ }^{9}$ Yet the Warsaw case is complicated. Bohdan Lachert's architectural attempt to represent the absence of Jewish life, while ultimately unsuccessful, was nevertheless significant and indeed anticipates to some extent Libeskind's project to represent the ruination of the Holocaust. The Berlin case is complicated as well: Libeskind's aspiration to represent ruination in architecture is hindered, if not concealed, by precisely the impulse to represent what eludes representation, and by the linear historical narrative that his building contains. In short, the tension of moving both toward and away from suffering and ruination courses through both cases.

The second affinity lies in what is at stake in these projects for both architects. Lachert and Libeskind both expressed an interest in creating architectural

representation (see notes 57 and 68), but it does not view the issue of representation in the terms that I explore here pertaining to the issues of ruination, absence, and death.

8 As I explain in some detail presently, the historical narrative is inherently holistic insofar as it seeks to reconstruct the reality of a lost world and does so typically through the creation of a linear narrative. Even if historians today may no longer purport to recreate the whole of a past event, as their nineteenth-century predecessors once did, they still claim to reconstruct a part of it; otherwise what might the historian be doing if not claiming to reconstruct a part of a past reality? Claiming to reconstruct the part obviously presupposes the presence or knowledge of the whole. The novelty of Libeskind's project lies in his aspiration to reflect on the absence of the whole.

9 I want to stress "almost entirely" here because there were some efforts to remember the Jewish past in the built environment such as the ghetto monument and the Jewish Historical Institute, which was located, significantly, where the old Tłómacka Street synagogue had once been. On the latter, see Jana Fuchs, "Der Nicht-Wiederaufbau der Warschauer Großen Synagoge und die Nutzung ihres Grundstücks nach dem Zweiten Weltkrieg," Zeitschrift für OstmitteleuropaForschung 62, 1 (2013): 40-75. 
projects that would stimulate public reflection on ruination so as to move beyond the traditional form of the monument. Conventionally, the monument has long sought to recuperate and immortalize what has passed away. It has been oriented toward salvation, understood as freedom from the pure ephemerality of time and the recovery of the past from oblivion. The conventional monument seeks to establish a sense of permanency. This orientation toward permanency smooths over or entirely forgets the ruination and rupture of history. In contrast, Lachert and Libeskind seek to perpetuate a kind of non-salvific memory that confronts ruination, death, and absence. At stake for them is promoting a form of remembrance that mourns the absence of prewar Jewish life and thereby avoids the salvific impulse to recuperate history so as to overcome the pure transience of time. Hence, both of these cases involve creative reactions to ruination that differ considerably from the dominant tendencies of their times, tendencies that have coursed through European history since the ancient period. ${ }^{10}$ In this respect, Lachert and Libeskind wittingly stood outside the shared, collective reactions to ruination that shaped their respective eras and the traditions in which they worked as artists. ${ }^{11}$

The essay has three parts. The first argues that Lachert's unconventional attempt to reflect on the absence of Warsaw Jewry fell victim to the impulse to harness the wartime past for the political needs of the present, specifically for the Communist Party's campaign to ground its authority in a historical narrative of national rebirth crafted both literally and metaphorically through the rebuilding of Poland's capital. The essay's second part emphasizes the ambition of Libeskind's effort to represent absence, and examines the constraints inherent in the content and form of his project. A final section brings these cases together as novel, if circumscribed attempts to reflect on absence and ruination in the postwar period.

\section{THE RUINS OF THE WARSAW GHETTO}

Since 2010, the video Miasto Ruin (City of ruins) has been showing in the Warsaw Rising Museum. It seeks to recapture the death and destruction of Warsaw in $1945 .{ }^{12}$ Created from 1,600 historical pictures, it provides a

\footnotetext{
10 As Hannah Arendt astutely notes, the salvific impulse of the historical narrative to recuperate and immortalize what has passed away can be traced back at least to Homer. The writing of history commences when Odysseus hears Demodocus tell of his past deeds: "History as a category of human existence is of course older than the written word, older than Herodotus, older even than Homer. Not historically but poetically speaking, its beginning lies rather in the moment when Ulysses, at the court of the king of the Phaeacians, listened to the story of his own deeds and sufferings, to the story of his life, now a thing outside himself, an 'object' for all to see and to hear"; "The Concept of History," in Between Past and Future (New York: Penguin, 1993), 45.

11 Regarding this point about virtuoso authorship, I thank one of the CSSH readers for bringing my attention to this important aspect of Lachert and Libeskind's projects.

12 Of Warsaw's 25,498 buildings, 11,229 were demolished and approximately 25 percent of its streets were destroyed. See Krystyna Czarnecka, Grażyna Kurpiewska, and Joanna Szapiro-Nowakowska,
} 
"fly over" of Warsaw's charred landscape, documenting the near total destruction of the city's old town before then coming to a field of crushed stone, an area that stands out, even in postwar Warsaw, for its ruination. ${ }^{13}$ Mounds of shattered stone, twisted beams, broken glass - this is the space of the former Warsaw ghetto, the space that had once comprised the main area of Jewish life in the city. ${ }^{14}$ In 1945, the area, known as Muranów, existed only as one gigantic ruin. "Around us, over a wide area, there was nothing but powdered rubble - ruins, ruins, ruins," one Jewish survivor observed. "It was impossible to believe that destruction could be so complete." 15 A stunning aerial photo taken of the ghetto in 1945 shows an area flattened almost entirely.

If one visits Warsaw today, one will find almost no artifacts of the area's wartime destruction. Nearly all the physical traces of the catastrophe of the Warsaw ghetto have either been cleared away or concealed by new buildings. This erasure may not surprise urban historians, since cities have been reconstructed anew many times before, and Warsaw's urban planners clearly had to rebuild their city in some manner. ${ }^{16}$ Even so, the sheer extent of the postwar erasure of Muranów is striking, a point that Jewish visitors noted. In 1958-1959, Abraham Michael Rosenthal of the New York Times, whose international reporting garnered him a Pulitzer Prize, lived in Warsaw, where he occasionally visited the former space of the ghetto. On the occasion of the twenty-fifth anniversary of the ghetto uprising he recalled his first visit to

\footnotetext{
"Straty w nieruchomościach," in Straty Warszawy 1939-1945. Raport (Warsaw: Urząd Miasta Stołecznego Warszawy, 2005), 373; Tomasz Stanisław Markiewicz, "Powrót do życia—Warszawa leczy rany zadane wojną," also in Straty Warszawy, 618.

13 The video can be viewed at www.youtube.com/watch?v=twDouTqS4c8 (last accessed 20 Nov. 2016).

14 In 1938, 90.5 percent of the inhabitants of Muranów were Jewish (Zalewska, Ludność, 63). Although Muranów was not a ghetto as defined as a compulsory, segregated, and enclosed area of Jewish residence (such as Frankfurt's Judengasse until the early nineteenth century), it was often imagined and discursively marked as a "ghetto." For discussion on Muranów and the spatial history of Jewish life in Warsaw, see Eleonora Bergman, "The 'Northern District' in Warsaw: A City within a City?" in Monika Murzyn-Kupisz and Jacek Purchla, eds., Reclaiming Memory: Urban Regeneration in the Historic Jewish Quarters of Central European Cities (Kraków: International Cultural Centre, 2009), 287-99; Barbara Engelking and Jacek Leociak, The Warsaw Ghetto: A Guide to the Perished City, Emma Harris, trans. (New Haven: Yale University Press, 2009), 1-24; Peter J. Martyn, "The Undefined Town within a Town: A History of Jewish Settlement in the Western Districts of Warsaw," in Władysław Bartoszewski and Antony Polonsky, eds., The Jews in Warsaw: A History (Cambridge: Blackwell, 1991), 55-83; Katrin Steffen, "Connotations of Exclusion-'Ostjuden,' 'Ghettos,' and other Markings,' Simon Dubnow Institute Yearbook 4 (2005): 459-79; Alina Cała, "The Discourse of 'Ghettoization'-Non-Jews on Jews in 19th- and 20th-Century Poland,” Simon Dubnow Institute Yearbook 4 (2005): 445-58; Gabriela Zalewska, Ludnosść żydowska $w$ Warszawie $w$ okresie międzywojennym (Warsaw: PWN, 1996).

15 Bernard Goldstein, The Stars Bear Witness (New York: Viking, 1949), 286.

16 In other words, leaving an entire area right in the heart of a capital city in ruination would have been less than feasible. Warsaw was not Oradour-sur-Glane. See Sarah Farmer, Martyred Village: Commemorating the 1944 Massacre at Oradour-sur-Glane (Berkeley: University of California Press, 1999).
} 


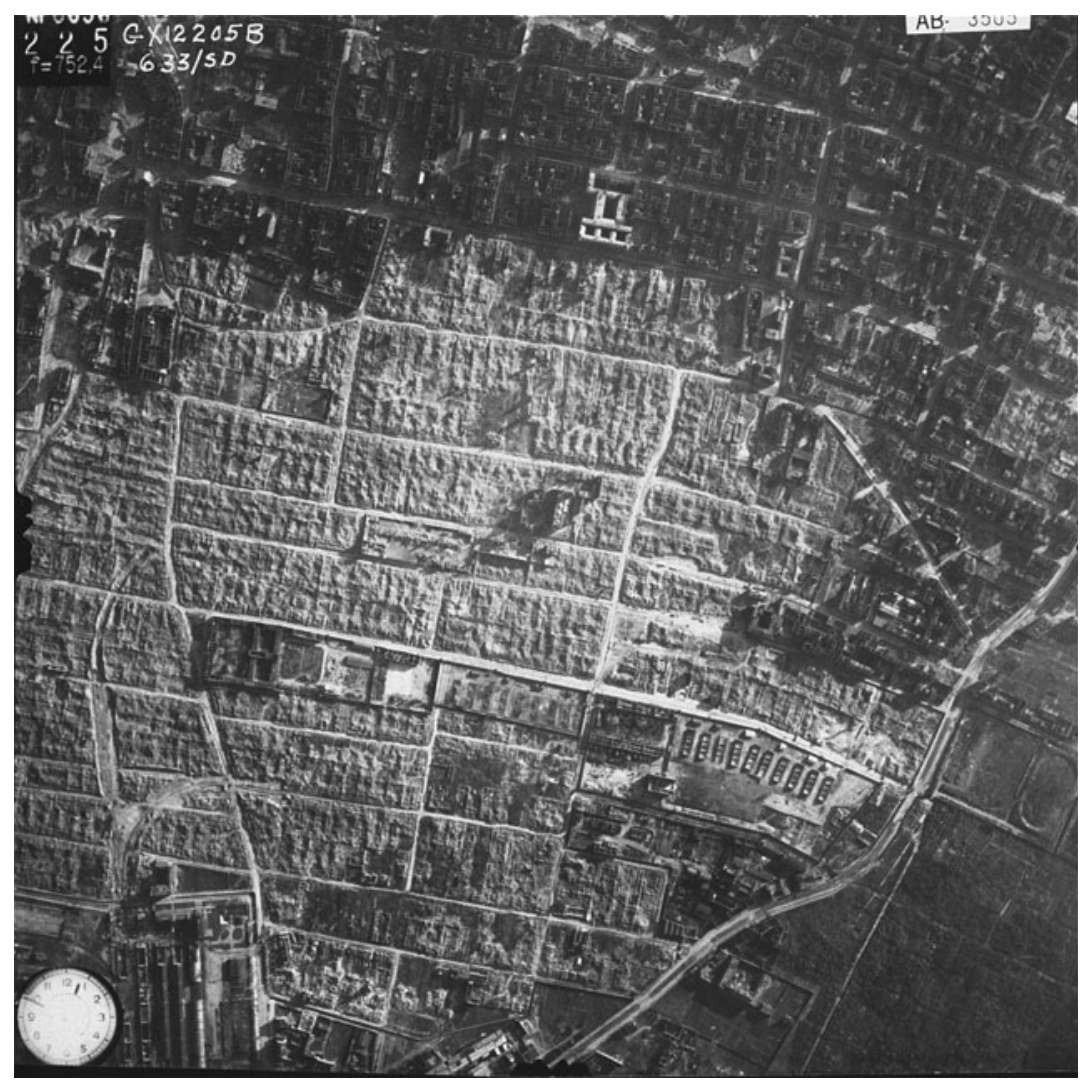

Figure 2 Aerial view of the destroyed Warsaw Ghetto on 16 May 1943. National Archives and Records Administration, College Park, courtesy of the United States Holocaust Memorial Museum. The views or opinions expressed in this article and the context in which the image is used do not necessarily reflect the views or policy of, nor imply approval or endorsement by, the United States Holocaust Memorial Museum.

Muranów. Looking at the ghetto space, with his wife and a young Jewish writer living in Warsaw, he wrote: "It was early in the morning; about 2 or 3 o'clock, and he took us out of the old part of town into a terrible emptiness. I said: 'What is it?' and he said it was the ghetto. There were some apartment buildings on the edges of the emptiness and they seemed awkward and strange, standing on what looked like mounds. I said, 'Why are the built like that?' and he said they were built on the remains of buildings and bodies and rubble of the ghetto, because it was cheaper that way."17

17 A. M. Rosenthal, "Forgive Them Not, for They Knew What They Did," New York Times, 24 Oct. 1965. 
Rosenthal provides an image of the new Muranów that was taking form in the early 1950s. The rebuilding of the district stemmed from plans for Warsaw's rebuilding that emerged immediately after the war and that came from a group of leftwing, avant-garde architects who had formed the backbone of interwar Poland's small, yet active modernist movement. Centered mainly at the Warsaw Polytechnic School of Architecture, the modernist milieu, which included architects such as Roman Piotrowski, Helena and Szymon Syrkus, Barbara and Stanisław Brukalski, Bohdan Lachert, and Józef Szanajca, followed international developments in Germany, France, and the United States and worked to apply modernist, functional designs to Warsaw's notoriously chaotic, cramped urban layout. Publishing articles in experimental journals such as Blok and Praesens, these architects focused mostly on providing solutions to housing and became involved in international discussions about modern architecture through meetings such as the Congrès Internationaux d'Architecture Moderne (CIAM). ${ }^{18}$ During the Nazi occupation, they joined together to form the underground Architecture and Town-Planning Studio (Pracownia Architektoniczno-Urbanistyczna, or PAU) that worked on plans for Warsaw's eventual reconstruction.

In 1945, Poland's Communist provisional government created the Office for the Rebuilding of the Capital (Biuro Odbudowy Stolicy, BOS) that oversaw Warsaw's reconstruction. Filling the ranks of BOS, Poland's interwar architects now had the unprecedented opportunity to create in practice what before they had only imagined on paper: a modern, functional Warsaw of green areas, socially progressive housing complexes, and a sensible transportation system. ${ }^{19}$ Created for a maximum population of 1.2 million, the first plan for Warsaw organized the capital into functional parts of housing, industry, leisure, green space, and areas for work. ${ }^{20}$ The design was received enthusiastically in Poland, and then warmly in the United States during a tour entitled "Warsaw Lives Again.,"21

In 1949, Poland's Communist Party announced the "Six-Year Plan for the Reconstruction of Warsaw" that guided the bulk of the capital's rebuilding. ${ }^{22}$ The plan kept with the basic modernist, functional design intended to alleviate

\footnotetext{
18 Adam Milobedzki, "Polish Architecture in the Period 1918-1939," Rassegna (1996): 6-13; Jadwiga Roguska, "The Radical Avant-Garde and Modernism in Polish Interwar Architecture," Rassegna (1996): 14-37.

${ }^{19}$ Initial plans drew on ideas developed by Szymon Syrkus and Jan Chmielewski in their "Functional Warsaw" (Warszawa Funkcjonalna), presented at the 1933 CIAM meeting: Warszawa funkcjonalna: Przyczynek do urbanizacji regjonu Warszawskiego (Warsaw: SARP, 1935).

${ }^{20}$ Stainsław Dziewulski, Adam Kotorbiński, and Wacław Ostrowski, "Zadanie odbudowy Warszawy,” Studia Warszawskie, vol. 11 (Warsaw: PWN, 1972), 294-317.

${ }^{21}$ Stanisław Albrecht, Warsaw Lives Again (Committee on Exhibition, "Warsaw Lives Again," 1946).

${ }_{22}$ Bolesław Bierut, Six-Year Plan for the Reconstruction of Warsaw (Warsaw: Polskie Wydawn. Gospodarcze, 1949).
} 
the city's cramped layout, but departed from earlier proposals in several key ways. Although socialist realism, with its monumental, ornamental, and representative architecture, had yet to fully shape the rebuilding of Warsaw, the ideological basis for building a "socialist city" became much more clearly articulated in the Six-Year Plan. The plan stressed two main elements of the socialist Warsaw: the development of industrial production as befitting a "city of workers," and the building of new housing complexes that transcended the cramped, poorly accommodated tenement houses of the capitalist, bourgeois past, which had deprived the workers of "greenery, recreation grounds, and cultural facilities." 23

Muranów was an important area in the center of the city for the regime's socialist aspirations. From its earliest plans, BOS decided to turn Muranów into a large housing complex as the cornerstone of Warsaw's transformation into a socialist city. ${ }^{24}$ Because Muranów was a cramped tenement area, it became one of the main areas for implementing the new socialist conception of housing that purported to transcend the limitations of capitalism. However, Muranów presented a particularly difficult task for BOS's architects, who had to deal with not only the enormous amount of rubble, especially in the northern part of the district which had been flattened completely, but also the history of the space itself. Most urban planners initially paid little or no attention to the area's history. The first plans for the district, published in 1946-1947, focused on the details of the housing complex to be built there. ${ }^{25}$

Then, in 1948-1949, a new architect, Bohdan Lachert, took over the project and proved to be more interested in reflecting on the area's history than any other designer that worked on it before or after him. ${ }^{26}$ Although Lachert set out to transform Muranów into a new housing complex of square, functional, and unadorned apartment buildings, he sought to at the same time express the particular history of the space upon which his buildings were to be erected. This was no easy task: how could one possibly memorialize in a housing complex? Lachert's answer-albeit subtle, if not oblique-was to leave the front of his buildings un-stuccoed and use a rusty red brick, with the intention of capturing the ghetto's somberness. As he put it, "The history of the great victory of the nation paid for through a sea of human blood, poured out for

\footnotetext{
23 Ibid., 125, 77.

24 "Zarys nowej Warszawy: Referat kierownika BOS inz. Piotrowskiego na VII sesji KRN," Życie Warszawy, 23 May 1945: 3; APW, Biuletyn Wenętrzny BOS, 31 Jan. 1946: 3.

25 "Plan odbudowy Warszawy. Muranów," Skarpa Warszwaska 26 (1946): 2; "Muranówdzielnica mieszkaniowa," Architektura 1 (1947): 8-11.

${ }^{26}$ Muranów was rebuilt from 1949 to 1967, designed by Bohdan Lachert (Muranów South), Wacław Eytner (Muranów North), and Tadeusz Mrówczyński (Muranów West). See Warzawskie osiedla ZOR (Warsaw: Arkady, 1968), 25-35.
} 


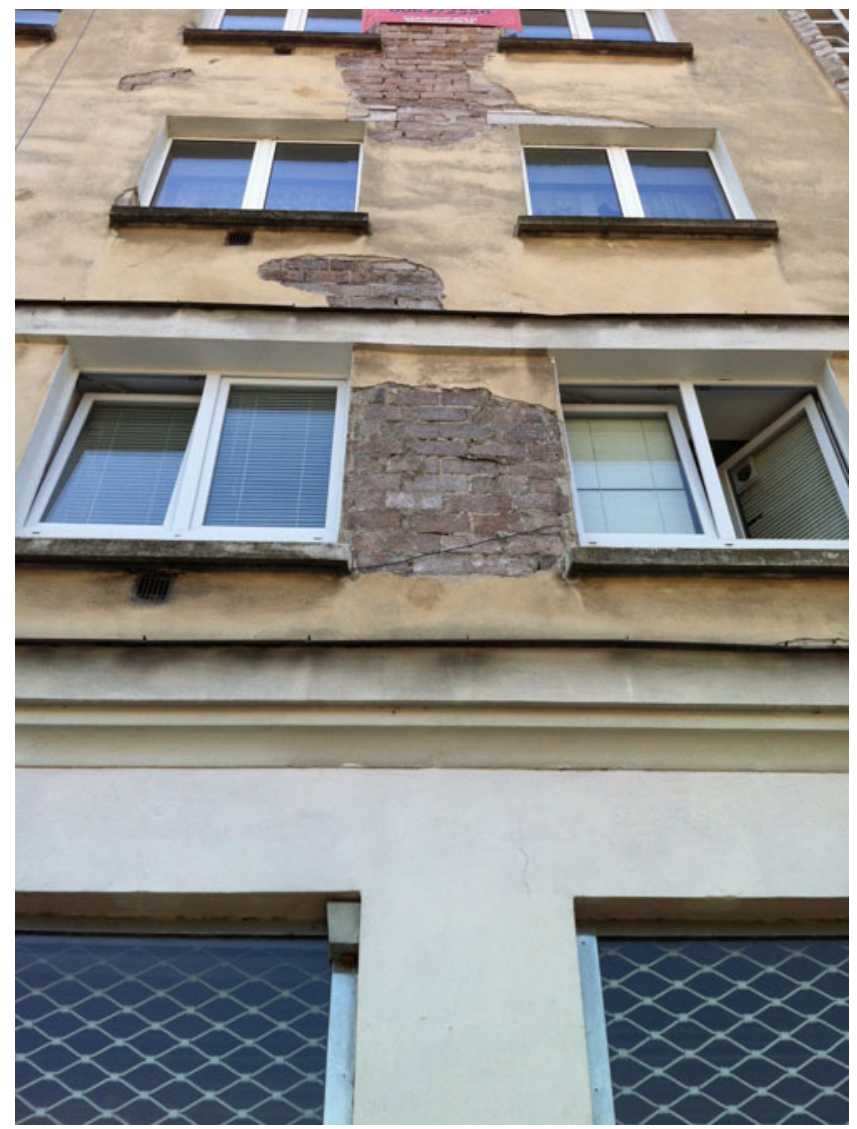

FiguRe 3 Few up-close, color photos of Lachert's red-brick façade exist. However, the socialrealist plaster of the 1950s is now peeling off. Photo by Michael Meng 2014.

the sake of social progress and national liberation, will be commemorated in the Muranów project.",27

Lachert saw his project as reinforcing the purpose of the Warsaw Ghetto Monument, which had just been erected in 1948, slightly to the north of his housing complex. The Central Committee of Jews, the leading Jewish organization in postwar Poland, had selected for the monument a design by the Polish-Jewish sculptor Natan Rapoport. It heroically commemorated the Warsaw Ghetto Uprising, depicting on its western side proletarian-looking figures brandishing arms as they seem to jump out from the granite in which

${ }^{27}$ Bohdan Lachert, “Muranów—Dzielnica mieszkaniowa," Architektura 5 (1949): 129, 132. 


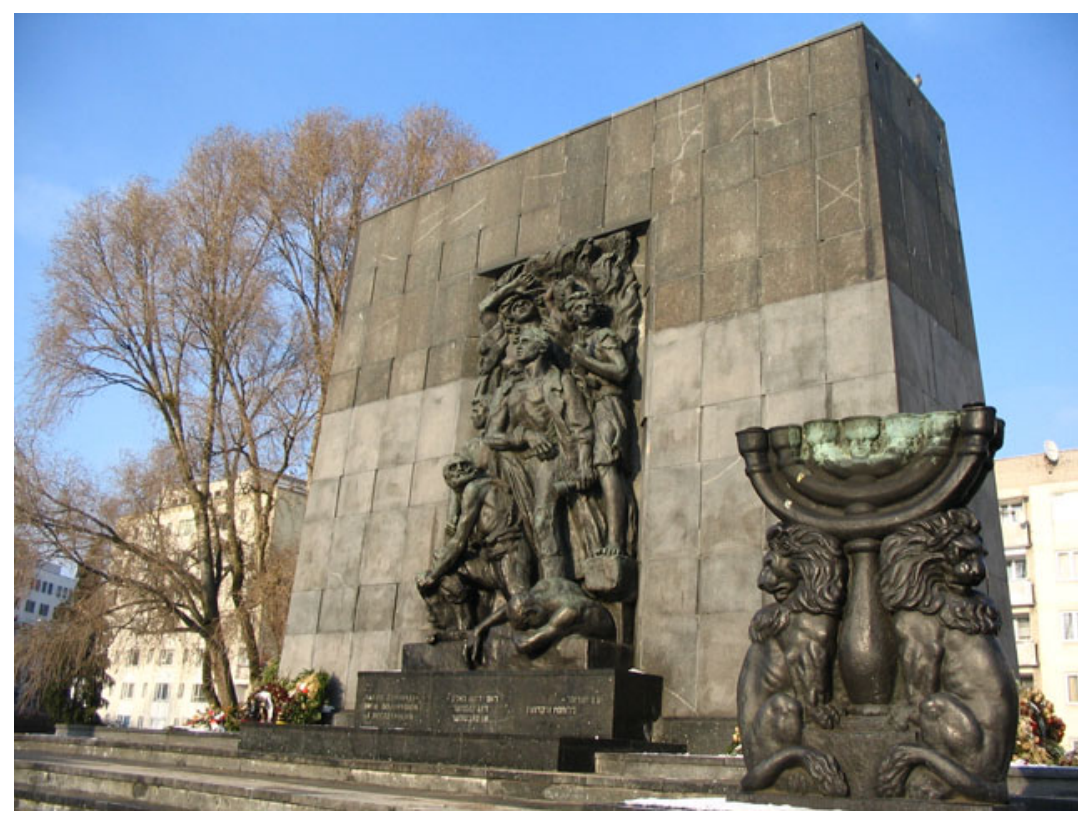

Figure 4 The Warsaw Ghetto Memorial. Photo by Michael Meng 2007.

they are carved. ${ }^{28}$ Lachert not only praised Rapoport's design but also insisted that it affirmed the memorial intentions of his housing complex:

The grim atmosphere of this great mausoleum, erected among a cemetery of ruins, soaked with the blood of the Jewish nation, should remain, as new life comes into existence. The architectural project, carried out in the rebuilding of Muranów, should not reduce these artistic elements, which the sculptor Rapoport created through a magnificent sculpture of bronze and granite.... The ruins, in the largest possible amount, should remain in place, remembering the days of terror and resistance, constituting the ground on which a new city, a new life will be raised. ${ }^{29}$

Lachert's intent was to incorporate the past into the Communist building of the future, an ambition with no precedent in this area of Warsaw. In effect, he envisioned his housing project as a monument to the dead that would be a burden on the future: the past would play a living role in the new Warsaw as a reminder of human suffering and as the foundation, so to speak, for building a new future beyond the violence and hatred of the past. His project issued in a bold call to reflect on suffering, death, and absence in early postwar Poland. This was precisely when the Communist regime was aiming to create a much different

28 James E. Young, Texture of Memory (New Haven: Yale University Press, 1993), 155-84.

29 Archiwum Żydowskiego Instytutu Historycznego (AŻIH), CKŻP, Wydział Kulury i Propagandy, Lachert report, 28 Apr. 1948, 308/217. 
future largely freed from or even oblivious to suffering, and the past in general, aside from its highly selective and overtly salvific effort to recuperate the "Polish" past for the purpose of legitimizing its power. Seeking to ground Communism in Polish history, the regime depicted Warsaw as a "martyr city" that was reemerging from near death under the benevolent and progressive rule of Communism. The central space appropriated for this narrative was Warsaw's heavily destroyed old town (stare miasto). In the opening essay to the first issue of Stolica, the illustrated weekly published by BOS, the task of resurrecting Warsaw's old town was framed as a sacrosanct act of national recovery. Surrounded by prewar pictures of Warsaw's Royal Castle, medieval Cathedral, and market square, the article suggested that the old town had to be reconstructed to demonstrate the immortality of the Polish nation:

Warsaw has her own eternal, living beauty. She has not lost it even now when many of her most beautiful monuments were totally exterminated. Whether it is the area of the Royal Castle, lying in a shapeless pile of ruins, the beautiful gothic cathedral, lying in one large heap of rubble, or the old-town market square where only three tenement houses remained in small fragments - this tragic spell rivets the people today and draws them to the ruins... There was no dispute, there were no two ways about it among Polish society that monuments of cultural and architectural value in Warsawfrom the Royal Castle to the Cathedral to the Old Town - must be resurrected.... The resurrected walls of the old town will not be a lifeless creation, but will stand as a living link connecting the past to the present and the future.... We are not a nation whose history began in January 1945 at the moment when the barbarians from the west were chased away. Our history dates back to the tenth century of the Christian era. ${ }^{30}$

Drawing on the deeply rooted notion of Poland as the "Christ among Nations"- a country crucified for the sins of the world that would return to rescue humanity - this article creates a basic salvation narrative by casting Warsaw as a martyr city that will overcome death. Warsaw's old town is not to be rebuilt but "resurrected" (wskrzesić) from ruination.

This salvific recovery of the past was starkly different from Lachert's reflection on the somberness of the ghetto space. He expressed no interest in resurrecting the prewar Jewish past. Rather, his architectural project attempted to represent the absence and ruination of this past. Whereas the reconstruction of the old town aspired to recover a lost past and overcome ruination, Lachert's project sought to mourn that past as ineluctably lost. Challenging the postwar propensity to flee from the death and destruction of history, Lachert's project tried to create, within the parameters available to him, a different relationship to the past, a different kind of memory, which was expressly not salvific in the metaphysical sense of striving to recuperate what has been lost. ${ }^{31}$ On the

\footnotetext{
30 “Piękno Warszawy której już niema, a która wskrzesimy,” Stolica, 3 Nov. 1946: 6.

31 Lachert's design was not salvific in the conventional, metaphysical sense of recuperating the past. It could, however, be interpreted as politically salvific to the extent that he envisioned turning back to the past so as to move into a more hopeful future. In this respect, he shares an affinity with Libeskind (see note 53).
} 
contrary, his architectural project intended to turn toward the suffering, death, and ruination of the ghetto.

The novelty of Lachert's project vis-à-vis the stare miasto deserves emphasis. The reconstruction of the old town was oriented towards affirming the indestructability of the Polish nation. It sought to deny the Nazi attempt to eliminate the history and culture of Poland through a monumental display of recovery and reconstruction. If Lachert's project obviously contributed to Warsaw's recovery, it was oriented toward a monumental display of fragility and suffering rather than indestructibility.

By 1949-1950, however, Lachert's novel project had come to an end. The modernist principles that had shaped it and much of Warsaw's reconstruction up to that point were rejected for the new architectural style-socialist realism-spreading across the Soviet bloc with the beginning of Stalinism. Originating in early 1930s Moscow, socialist realist architecture documented the historic triumph of Communism over capitalism by showcasing the historic movement from the dark, dirty, cramped, and chaotic capitalist city to the light, clean, spacious, and orderly socialist city. ${ }^{32}$ Its grandiose, ornamental style was imported into Eastern Europe in the late 1940s and early 1950s. When it arrived, Lachert's plans were criticized for their modernist expression and alleged gloomy representation of the ghetto space. ${ }^{33}$ The fallout was clear, and Lachert's buildings were stuccoed and small designs were painted on their white surfaces to make them conform to the formulaic principles of socialist realism. No deviation from the governing norm of socialist realism could be permitted, and Lachert's architectural attempt to express the ruination and absence of Warsaw Jewry was rejected.

Muranów was now definitively to be a space of the socialist future. ${ }^{34}$ The district was made to conform to the salvific narrative of Warsaw rising from ruination under the benign rule of Communism and, thus, the wartime history of Muranów was increasingly erased. To be sure, this erasure of the Holocaust was not completely hegemonic; the removal of the ghetto rubble hardly meant that individuals could not remember the area's traumatic history. Some Jews living in Muranów certainly nourished memories of the Holocaust. $^{35}$ Even so, the new housing complex involved a significant erasure of the past in public, collective memory, not least because humans

32 Katerina Clark, Moscow, The Fourth Rome: Stalinism, Cosmopolitanism, and the Evolution of Soviet Culture, 1931-1941 (Cambridge: Harvard University Press, 2011), 100-1. On building the new Moscow, see Karl Schlögel, Moscow, 1937, Rodney Livingstone, trans. (Malden: Polity, 2012), 33-53.

33 Jerzy Wierzbicki, “Dzielnica mieszkaniowa Muranów (Próba krytyki)," Architektura 9 (1952): 222-25.

34 "Tynkowanie Muranowa," Stolica, 15-31 May 1951: 3.

35 Karen Auerbach, The House at Ujazdowskie 16: Jewish Families in Warsaw after the Holocaust (Bloomington: Indiana University Press, 2013). 
powerfully express their collective memories in the ordering, marking, and commemoration of public spaces - what is and is not preserved matters. As Maurice Halbwachs suggests, "Since our impressions rush by, one after another, and leave nothing behind in our mind, we can understand how we can recapture the past only by understanding how it is, in effect, preserved by our physical surroundings." 36

So what was ultimately preserved for future generations in the socialist rebuilding of Muranów? It was the socialist narrative of rebirth from the devastation of Nazism. The new Muranów celebrated in the urban landscape the new beginning that Communism sought to commence in Poland, one that turned away from the suffering and death of the past to the new future of material prosperity and progress. According to press accounts, the district's transformation represented the movement away from the darkness of the past to the light of the Communist future. "New, bright houses grow on the ruins of the ghetto; a new life grows, which prevails over destruction and mass extermination. These houses and the forest of scaffoldings that are rising up throughout all of Warsaw are evidence to the constantly growing power of peace and socialism."37

The socialist rebuilding of Muranów turned away from the mass violence of the past. It reflected the desire, at least on the part of the Communist regime, to fill in the emptiness and absence of the ghetto space with the promise of the new Communist future. As President Bolesław Bierut put it in the Six-Year Plan, the new district would mark a bold departure from the past: "This year, on the ruins of the former ghetto, the Workers's Housing Society has started building Muranów which is to be the largest settlement in Warsaw."38 Perhaps the most powerful illustration of this turn away from the death and destruction of the ghetto can be seen through photos of the new district. One such photo captures a view of the new socialist district in 1959 with the stuccoing fully completed on the outside of Lachert's apartment buildings. As a space of the socialist future, the new district was now a bright and cheerful place that affirmed Warsaw's resurrection from death and ruination.

Although one cannot say definitively that this transformation of Muranów reflected a deliberate effort on the part of the Communist regime to forget the city's Jewish past, there is enough evidence to suggest that it was. ${ }^{39}$ The regime

\footnotetext{
36 Maurice Halbwachs, The Collective Memory, Francis J. Ditter, Jr., and Vida Yazdi Ditter, trans. (New York: Harper \& Row, 1980), 140.

37 "W ósmą rocznicę powstania w getcie," Trybuna Ludu, 19 Apr. 1951, 3.

38 Bierut, Six-Year Plan, 201.

39 A careful analysis of the regime's policy toward Jewish life in postwar Warsaw can be found in David Engel, "The End of a Jewish Metropolis? The Ambivalence of Reconstruction in the Aftermath of the Holocaust," in Glenn Dynner and François Guesnet, eds., Warsaw: The Jewish Metropolis. Essays in Honor of the $75^{\text {th }}$ Birthday of Professor Antony Polonsky (Leiden: Brill, 2015), 562-69. See also Marcin Zaremba, Komunizm, legitymizacja, nacjonalizm. Nacjonalistyczna legitymizacja władzy komunistycznej w Polsce (Warsaw: Trio, 2001).
} 


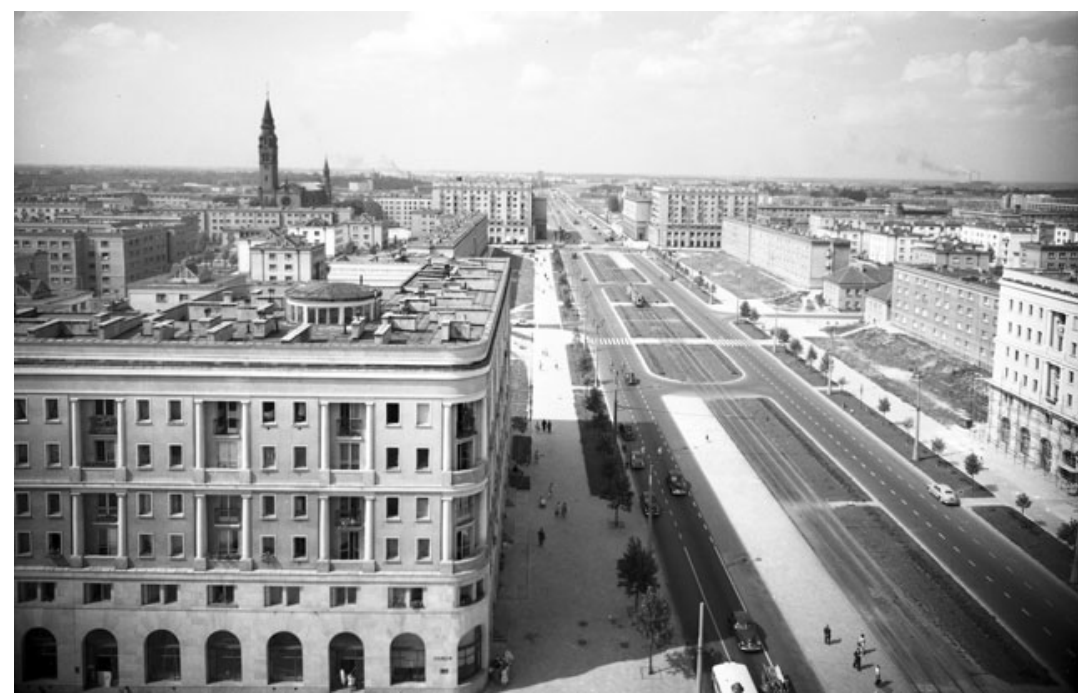

Figure 5 Postwar Muranów in 1959. Courtesy of Narodowe Archiwum Cyfrowe.

rebuilt Warsaw as an ethnically and culturally Polish capital. The great symbolic meaning it invested in the rebuilding effort told a story about the revival of the Polish nation after war and genocide. This narrative could most certainly have included Jews; exclusive imaginations of the Polish nation are historically contingent and need not necessarily exclude Jews. ${ }^{40}$ Yet, after the war, the regime generally embraced an ethnically and cultural exclusive imagination of the nation, as clearly evident in its reconstruction of Warsaw: whereas the ruins of Warsaw's stare miasto were venerated as sacred fragments of the Polish nation that had to be salvaged, the rubble of the ghetto was viewed as debris that could be cleared away for the building of the new future. Most strikingly, there were very few efforts by the regime to mourn the loss of Warsaw as a "Jewish metropolis." While Jews who returned to Warsaw immediately after the war saw Muranów for what it

40 Joanna Beata Michlic, Poland's Threatening Other: The Image of the Jew from 1880 to the Present (Lincoln: University of Nebraska Press, 2006); Brian Porter, When Nationalism Began to Hate: Imagining Modern Politics in Nineteenth-Century Poland (New York: Oxford University Press, 2000); Scott Ury, Barricades and Banners: The Revolution of 1905 and the Transformation of Warsaw Jewry (Stanford: Stanford University Press, 2012); Geneviève Zubrzycki, The Crosses of Auschwitz: Nationalism and Religion in Post-Communist Poland (Chicago: University of Chicago Press, 2006); Jonathan Huener, Auschwitz, Poland, and the Politics of Commemoration, 1945-1979 (Athens: Ohio University Press, 2003). 
was - a massive space of death - the regime did not. ${ }^{41}$ It was not until much later, and above all after the collapse of Communism, that efforts emerged again to reflect on Warsaw's Jewish past and the mass murder of its Jewish population during World War II. ${ }^{42}$

\section{THE BERLIN JEWISH MUSEUM AS A RUIN}

The ultimate forgetting of ruination in early postwar Warsaw can hardly be characterized as unique to Poland. It suggests one of two general European reactions to the Holocaust. ${ }^{43}$ The other reaction that I want to discuss involves the desire to represent absence and ruination through architecture. Though anticipated by Lachert's project, this desire emerged most visibly by the late 1980s and reflected two broad cultural and intellectual developments of the late postwar period: first, the growing awareness of the Holocaust in the public sphere in Western Europe and the United States, ${ }^{44}$ and second, the general tendency in continental thought to reflect on the ruptures and ruins of modernity in contradistinction to conventional historical narratives that either simply ignore the violence and suffering of history or seek to smooth it over through redemptive narratives of progress. ${ }^{45}$ This growing interest in

41 Evidence for the memories of Jews is particularly widespread in travelogues, many of which were written in Yiddish shortly after the war. See Jack Kugelmass, Sifting the Ruins: Émigré Jewish Journalists' Return Visits to the Old Country, 1946-1948, David W. Belin Lecture in American Jewish Affairs (Ann Arbor: The Jean \& Samuel Frankel Center for Judaic Studies, 2013).

42 See Konstanty Gebert, "Reading the Palimpsest," in Erica Lehrer and Michael Meng, eds., Jewish Space in Contemporary Poland (Bloomington: Indiana University Press, 2015), 223-37. On the broad context of memory in postwar Poland, see Huener, Auschwitz; Zubrzycki, Crosses of Auschwitz; Michael C. Steinlauf, Bondage to the Dead: Poland and the Memory of the Holocaust (Syracuse: Syracuse University Press, 1997); Hannah Maischein, Augenzeugenschaft, Visualität, Politik. Polnische Erinnerungen an die deutsche Judenvernichtung (Göttingen: Vandenhoeck \& Ruprecht, 2016); Zofia Wóycicka, Przerwana żałoba: Polskie spory wokót pamięci nazistowskich obozów koncentracyjnych i zagłady, 1944-1950 (Warsaw: Trio, 2009). For a recent study of contemporary memories, see Anna Wylegała, Przesiedlenia a pamięć: Studium (nie)pamięci społecznej na przykładzie ukraińskiej Galicji i polskich "ziem odzyskanych” (Toruń: Wydawnictwo Naukowe Uniwersytetu Mikołaja Kopernika, 2014).

${ }^{43}$ See Omer Bartov, Erased: Vanishing Traces of Jewish Galicia in Present-Day Ukraine (Princeton: Princeton University Press, 2007); Ruth Ellen Gruber, Virtually Jewish: Reinventing Jewish Culture in Europe (Berkeley: University of California Press, 2002); Marianne Hirsch and Leo Spitzer, Ghosts of Home: The Afterlife of Czernowitz in Jewish Memory (Berkeley: University of California Press, 2010); Michel Laguerre, Global Neighborhoods: Jewish Quarters in Paris, London, and Berlin (Albany: State University of New York Press, 2008); Meng, Shattered Spaces.

44 The literature on Holocaust memory in the United States and Europe is enormous. See, as a start, Peter Novick, The Holocaust in American Life (New York: Mariner, 2000); James E. Young, The Textures of Memory: Holocaust Memorials and Meaning (New Haven: Yale University Press, 1993); Harold Marcuse, The Legacies of Dachau: The Uses and Abuses of a Concentration Camp, 1933-2001 (New York: Cambridge University Press, 2001); Steinlauf, Bondage to the Dead; A. Dirk Moses, German Intellectuals and the Nazi Past (New York: Cambridge University Press, 2007); Joan B. Wolf, Harnessing the Holocaust: The Politics of Memory in France (Stanford: Stanford University Press, 2003).

45 For a general overview of this intellectual development in continental thought, see Mark Mazower, "Foucault, Agamben: Theory and the Nazis," boundary 2 35, 1 (2008): 23-34. 
the ruins of history was distinctly political. Just as Lachert's effort to reflect on the Warsaw ghetto contested the prevailing propensity in Communist Poland to turn away from the most recent past, so too did increased sensitivity to the darkest moments of twentieth-century history pose a challenge to the oblivion of consumerist capitalism in the post-industrial era. ${ }^{46}$

Few architectural projects express this impulse to reflect on absence and ruination more overtly than Daniel Libeskind's Jewish Museum. Shaped by Walter Benjamin's insistence on remembering the "wreckage" of the past lest it be forgotten by redemptive and ideological narratives of progress, Libeskind seeks to represent ruination in a newly constructed building. ${ }^{47}$ His project takes up the task of mourning by promoting reflection on the "erasure and void of Jewish life in Berlin." ${ }^{48}$ A striking photo of his building taken during its construction brilliantly illustrates this point. Included by Libeskind in a lecture delivered at the University of Michigan, the photo captures a structure that looks like a ruin. The picture shows a hollowed-out shell of an empty building.

It is precisely such emptiness that Libeskind wanted to integrate into his building. As he explains, "Cutting through the form of the Jewish Museum is a void, a straight line whose impenetrability forms the central focus around which the exhibitions are organized. In order to cross from one space of the museum to the other, the visitors traverse sixty bridges that open into the void space - the embodiment of absence." ${ }^{49}$ Absence seems central to his design almost out of necessity. It is as if Libeskind could not respond to the task of building a Jewish museum in Berlin after the Holocaust in any other way. In a way similar to Lachert, Libeskind suggests that the particular history of the space on which his building stands determines what he can create artistically:

The void and the invisible are the structural features which I have gathered in this particular space of Berlin and exposed in architecture. The experience of the building is organized around a center which is not to be found in any explicit way because it is not visible. In terms of this museum, what is not visible is the richness of the former Jewish contribution to Berlin. It cannot be found in artifacts because it has been

A more extensive intellectual history can be found in Stefanos Geroulanos, An Atheism that Is not Humanist Emerges in French Thought (Stanford: Stanford University Press, 2010).

${ }^{46}$ Adorno drew a direct link between consumerist capitalism and forgetting in his famous essay on West Germany during its "economic miracle." See Theodor W. Adorno, "The Meaning of Working through the Past," in Critical Models: Interventions and Catchwords, Henry W. Pickford, trans. (New York: Columbia University Press, 1998), 89-104; Michael Meng, "The Amnesia of the Wirtschaftswunder: Essen's 'House of Industrial Design,"' Jewish Culture and History 18, 1 (2017): 5-16.

${ }^{47}$ Walter Benjamin, "Theses on the Philosophy of History," in Illuminations, Hannah Arendt, ed., Harry Zohn, trans. (New York: Schocken Books, 2007), 257-58.

${ }^{48}$ Daniel Libeskind, "Between the Lines: Jewish Museum, Berlin 1988-99," in The Space of Encounter (New York: Universe Publishing, 2000), 23.

49 Ibid., 28. 


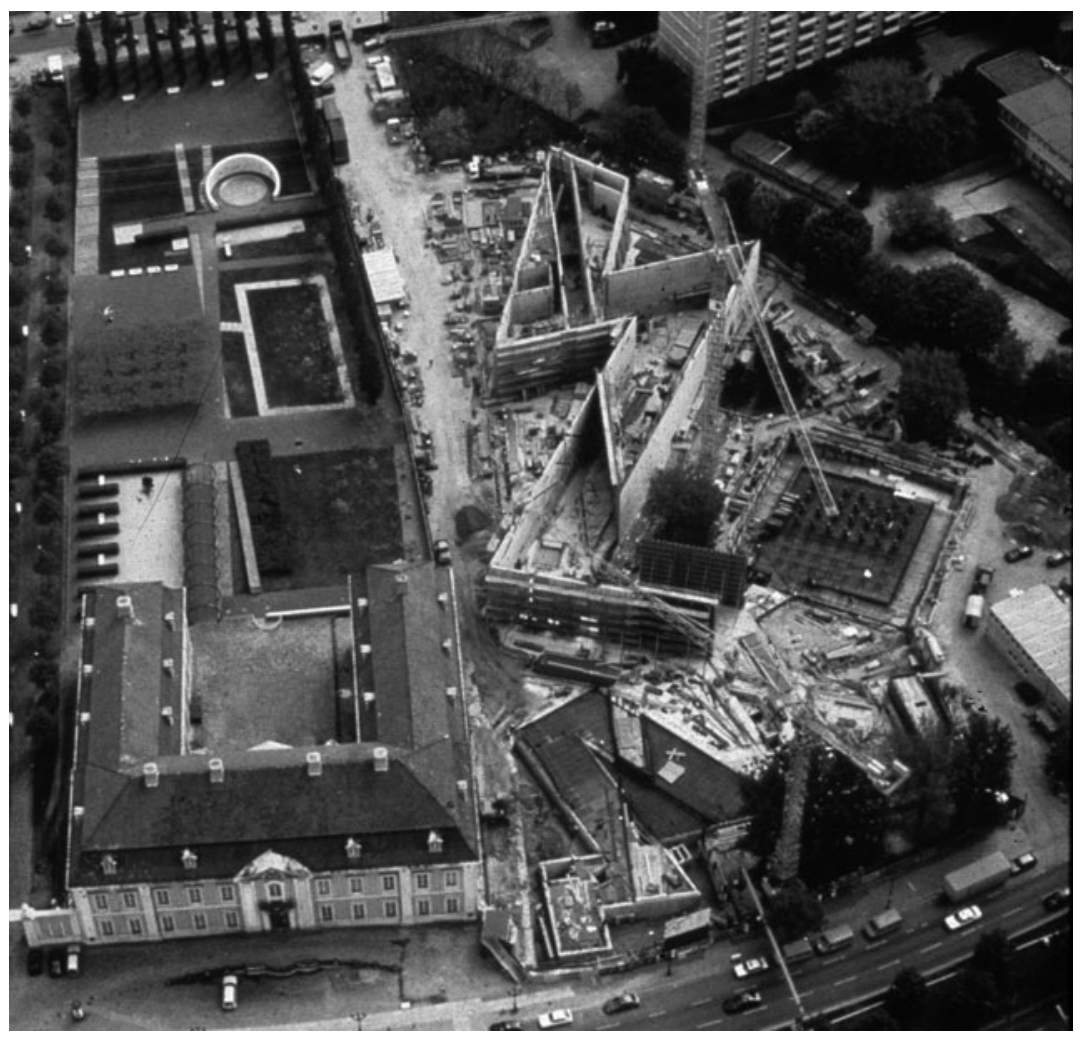

FigURE 6 Berlin's Jewish museum appearing as if it were a ruin. (C) Studio Daniel Libeskind. Photo by Manfred Beck.

turned to ash. It has physically disappeared. This is part of the exhibit: a museum where no museological functions can actually take place. ${ }^{50}$

Libeskind makes two claims here regarding the importance of history to his project. The first is that the Holocaust overshadows the previous history of Berlin Jewry since the traces of past Jewish contributions to Berlin have been destroyed. The second is that the museum cannot serve any museological function for reasons that Libeskind does not specify but which we might surmise as the following: first, that the rupture of the Holocaust has rendered the task of telling the history of German Jewry in the conventional form of the narrative difficult, and second, that the suffering and death of the victims

50 Daniel Libeskind, Traces of the Unborn (Ann Arbor: University of Michigan College of Architecture and Urban Planning, 1995), 35. 
cannot be used for any traditional pedagogical purpose because to do so would be to instrumentalize the Holocaust as an object of educational study. Libeskind's project calls into question the conventional historical and pedagogical aim of salvaging some kind of meaning from history. ${ }^{51}$ As James Young writes, Libeskind's project represents "an aggressively antiredemptory design, built literally around an absence of meaning in history, an absence of the people who would have given meaning to their history." 52

Young briefly touches on one of the most novel aspects of Libeskind's project. In centering his design on absence and ruination, Libeskind commits himself to a commemorative project that seeks nothing more than to mourn the suffering of the victims and the catastrophe of history. ${ }^{53}$ It tries to perpetuate a non-salvific form of memory that reflects on the rupture of history rather than evading it as the conventional historical narrative does with its propensity to create a sense of continuity from the discontinuity and rupture of history.

The underlying issue here is history, or time. The historical narrative orders time into a cohesive and fixed account. This ordering of time rests on an unquestioned assumption about the "essence" of time. The historical narrative assumes an answer to the classic question: What is time? The answer given, since Aristotle, is that time represents the number of motion. ${ }^{54}$ This concept of time suggests that there is some kind of "natural" or "raw" continuous sequence that can be calculated and organized into the historical narrative. By taking as self-evident the past as a continuous passing of something, the historical narrative presupposes that the past can be put back together in its original wholeness as if it were a broken piece of pottery. It is precisely this restorative or redemptive impulse that Libeskind's project brings into question. The past cannot, his project suggests, be salvaged and restored; history can only be represented as a ruin, as a collection of shards, as fragments that resist the narrative urge to bring them into a whole again.

Put differently, Libeskind commits himself to an artistic response to the Holocaust that comes close to embracing Adorno's claim that it would be callous to derive meaning from history. "After Auschwitz," Adorno writes, "our feelings resist any claim of the positivity of existence as sanctimonious,

51 Karl Löwith, Meaning in History (Chicago: University of Chicago Press, 1949); Jacob Taubes, Occidental Eschatology, David Ratmoko, trans. (Stanford: Stanford University Press, 2009).

52 Young, Memory's Edge, 179.

53 There is, however, ambiguity in Libeskind's thinking on this matter. While he emphasizes perpetual mourning and remembrance, he also nourishes hopeful possibilities of transformation in a much more affirmative way than Adorno would. His project aims "to express how, through the acknowledgment of a particular form of absence, life can have meaning and an optimistic, hopeful direction." Libeskind, Traces of the Unborn, 33.

54 See Martin Heidegger's discussion of time as the number of motion (arithmos kineseos), in The Basic Problems of Phenomenology, Albert Hofstadter, trans. (Bloomington: University of Indiana Press, 1988), 239-40. 
as wronging the victims; they balk at squeezing any kind of sense, however bleached, out of the victims' fate." 55 For Adorno, suffering is central to history and the conventional attempt to give meaning to suffering through the historical narrative has collapsed after the Holocaust. One can only mourn past suffering. Mourning can remind us of the vulnerability that each of us faces as suffering beings and thereby strengthen a normative commitment to egalitarianism, but it cannot create a collective identity and memory around some kind of meaning imposed on the past for the needs of the present.

That Libeskind endeavors to realize Adorno's philosophical warning in an artistic project reflects great ambition and originality on his part, but his project faces two central challenges in doing so. The first concerns Libeskind's effort to represent absence in a building otherwise devoted to providing a cohesive historical narrative about German Jewry. If historical narratives offer continuity and order to the rupture of history, then a significant tension seems to exist between his project's content and its form, ${ }^{56}$ for Libeskind's design explicitly challenges the conventional purpose of the historical narrative by insisting on absence and ruination. "Although the program originally called for a chronological display," Libeskind writes, "I have introduced the idea of the void as a physical interference with chronology." ${ }^{, 58}$ How does the void interfere with chronology? I think what Libeskind means is that the void challenges how the chronological, narrative account of history typically approaches history. Let me clarify this point by turning to an important distinction made in the German language between Historie and Geschichte: the word Historie, which derives from Latin, is the narrative told about a past event, whereas Geschichte, which comes from the German verb geschehen, is the past itself, the happening, the event. Geschichte is the dynamic unfolding of time that Historie aims to capture, order, and structure.

As a type of Historie, chronology orders Geschichte into a cohesive and holistic narrative. It turns away from absence by seeking to make the past present again, whereas Libeskind's project tries to turn toward absence by making it "the one element of continuity throughout the complex form of the building.,"59

\footnotetext{
${ }_{55}^{55}$ Adorno, Negative Dialectics, 361.

${ }^{56}$ See Paul Ricoeur, Time and Narrative, vol. 1, Kathleen McLaughlin and David Pellauer, trans. (Chicago: University of Chicago Press, 1990).

${ }^{57}$ In the field of Holocaust studies, this challenge has also been taken up by historians who have reflected on the limits of historical narration and representation. See Saul Friedländer, Probing the Limits of Representation: Nazis and the "Final Solution" (Cambridge: Harvard University Press, 1992); Dominick LaCapra, Writing History, Writing Trauma (Baltimore: Johns Hopkins University Press, 2001); Dan Stone, "Surviving in the Corridors of History or, History as Double or Nothing," in Jeffrey R. Di Leo, ed., Federman's Fictions: Innovation, Theory, and the Holocaust (Albany: State University of New York Press, 2011), 203-14.

${ }_{58}$ Libeskind, Traces of the Unborn, 34.

59 Ibid.
} 
If Libeskind's project seeks to approach Geschichte differently than Historie does, then a central tension between content and form courses through his project: while the exhibition makes German Jewish history present again through the chronological narrative, the building challenges precisely the narrative recuperation of Geschichte through its "embodiment of absence." ${ }^{, 60}$ Libeskind's building suggests that Geschichte cannot be recovered or made present again - it is a ruin that cannot be repaired. Now, one might say that this tension confirms the disruptive brilliance of Libeskind's art, and perhaps that is a fair point. But this point hinges on the very possibility of representing absence and ruination. Can absence be represented in a fully present building? Can a fully constructed building be a ruin of sorts?

These questions bring us to the second challenge of Libeskind's project, a challenge that Jacques Derrida raised, if briefly, in the "anxious question" that he posed to Libeskind about his void, "this determined void of yours, totally invested with history, meaningfulness, and experience." ${ }^{61}$ As Derrida explains, Libeskind's void is made visible, determinate, and full of meaning. Put simply, it turns out not to be a void at all:

This void which has to be made visible is not simply any void. It is a void that is historically determined or circumscribed; and it is not, for example, the indeterminate place in which everything takes place. It is a void that corresponds to an experience which somewhere else you have called the end of history - the Holocaust as the end of history.... The void you are determining here is the void as determined by an event - the Holocaust — which is also the end of history. Everything is organized from this end of history and from this void- this is what makes it meaningful. ${ }^{2}$

Derrida claims that Libeskind's project turns out to affirm the metaphysical habituation to meaning and presence that it purports to challenge. Not only does Libeskind's project make absence present but it also inscribes the void within a stable and particular framework of historical meaning based on a determinate end. The Holocaust becomes the telos of Libeskind's project, the end that gives meaning to his void. Derrida suggests that Libeskind ends up turning away from absence insofar as he gives it a determinate form. His void conceals the emptiness it seeks to represent by attempting to represent it. By doing so, his project remains entrapped within the metaphysical tradition. Strive as one may to move beyond metaphysics, one can only ever fail to reach a new shore beyond it. ${ }^{63}$

${ }^{60}$ Libeskind, "Between the Lines," 28.

${ }^{61}$ Derrida, "Response to Daniel Libeskind," 93.

${ }^{62}$ Ibid.

${ }^{63}$ This failure affirms the differential interplay of presence and absence. At stake for Derrida is demonstrating that no one meaning or narrative may become authoritative: a final meaning never comes, so we have many attempts at meaning and representation, none of which can succeed. 
Derrida's critique opens up the central problem that any artist or writer faces, from the architect to the painter to the historian. ${ }^{64}$ To wit, can one move beyond the limits set by the contexts of a tradition? In Libeskind's case the question becomes: Can there be a new kind of memory that transitions beyond the metaphysical orientation towards meaning, purpose, and redemption? ${ }^{65}$ And if there can, then how might that memory be described? What is a memory absent meaning or sense? What is a memory of emptiness, absence, nothingness?

Hence, we might be left with appreciating Libeskind's project solely in terms of distinguishing it from what it aims not to do-in terms of what it tries to leave behind in its focus on absence. At its most suggestive, Libeskind's art strives to move beyond the conventional purpose of history as a form of salvation from the ruptures of history by creating a monument of absence and ruination.

\section{MONUMENTS OF RUINATION}

In this respect, Libeskind's project overlaps with Lachert's housing complex in Muranów. Although they are situated in different places and time periods, both come together in their analogous attempt to reflect on ruination and absence. To be sure, this is more directly expressed in Libeskind's project than it possibly could have been in Lachert's design for a Communist housing complex. But Lachert intended to memorialize the suffering of the ghetto. As mentioned earlier, he served on an expert panel that commented on Natan Rapaport's now famous ghetto memorial, which was unveiled in 1948. In his commentary on the monument, Lachert stressed that the "grim atmosphere of this great

\footnotetext{
64 Indeed, Derrida develops the same fundamental concern at much greater length in his engagement with Foucault's effort to write a history of madness. Can a history of madness be told through the language of reason? Can one speak of madness without turning it into its other? Derrida ultimately insists that one cannot; Foucault's ambitious project to describe madness - that which is irrational - through reason is bound to fail by virtue of the imperialistic acquisition of reason itself: "The misfortune of the mad, the interminable misfortune of their silence, is that their best spokesmen are those who betray them best; which is to say that when one attempts to convey their silence itself, one has already passed over to the side of the enemy, the other side of order, even if one fights against order from within it, putting its origin into question. There is no Trojan horse unconquerable by Reason (in general). The unsurpassable, unique, and imperial grandeur of the order of reason, that which makes it not just another actual order or structure (a determined historical structure, one structure among other possible ones), is that one cannot speak out against it except by being for it, that one can protest it only from within it; and within its domain, Reason leaves us only the recourse to stratagems and strategies." Jacques Derrida, "Cogito and the History of Madness," in Writing and Difference, Alan Bass, trans. (Chicago: University of Chicago Press, 1978), 36.

65 Derrida, for one, denies that one can get out of the metaphysical tradition in his critique of Martin Heidegger, who tries to do so in his writings of the 1930s, especially in Contributions to Philosophy (of the Event). See Jacques Derrida, Of Spirit: Heidegger and the Question, Geoffrey Bennington and Rachel Bowlby, trans. (Chicago: University of Chicago Press, 1989), 31-36.
} 
mausoleum, erected among a cemetery of ruins, soaked with the blood of the Jewish nation," must remain as "new life comes into existence.",66

The novelty of both of these memorial efforts warrants emphasis. If viewed from a broad historical perspective, monuments that intend to promote reflection on rupture and absence are atypical. The concept of the monument from its origins in the written record of European history has typically sought to nourish bonds of continuity, bonds that seek to overcome the pure evanescence of time and the finality of death. ${ }^{67}$ The traditional monument immortalizes through stone. ${ }^{68}$ The permanency it strives to establish may be individual or collective: one might build a monument to an individual whose life one wishes to commemorate, or one to an entire group of people whose actions and values one wishes to perpetuate across generations.

In contrast, the Libeskind and Lachert projects, like a number of others in the postwar period, intend to nourish a different kind of remembrance that reflects on discontinuity, absence, and death. ${ }^{69}$ If both projects obviously promote continuous remembrance, it is a remembrance that calls attention to absence and ruination - it is a remembrance that undermines the traditional purpose of the monument. Having said that, both memorial efforts were limited by the conventional demands of memorialization under which the two men worked. In Lachert's case, the demands came from the Communist Party, which sought to ground its authority in a national narrative of rebirth. His reflection on the ghetto space challenged this salvation narrative and the party ultimately rejected it. It then appropriated Muranów as a space to showcase its effort to bring Warsaw from the darkness of the past to the light of material prosperity-from reflection to oblivion. In the case of Libeskind, his intentions were hindered in two ways: (1) by the form of his memorial project, as Derrida noted in his critique of Libeskind's effort to represent ruination and absence in a newly constructed building; and (2) by the historical,

66 Archiwum Żydowskiego Instytutu Historycznego, Centralny Komitet Żydów w Polsce, Wydział Kultury i Propagandy, 308/217, Bohdan Lachert report, 28 Apr. 1948. For additional evidence on Lachert's intentions, see Lachert, "Muranów_-Dzielnica mieszkaniowa" and "Historia powstania osiedli Muranowa Południowego," excerpts from an unpublished manuscript of which are published in Piotr Matywiecki, Kamień graniczny (Warsaw: Oficyna Wydawnicza Latona, 1994), 491-94.

67 The ancient Greek word for monument ( $\mu \nu \eta \mu \varepsilon \tilde{o v} / m n \bar{e} m e i o n)$, for example, is used in both cases in Thucydides' The Peloponnesian War (1:138, 2:41, and 5:11).

68 Though stone "gives a false sense of continuity," in Lewis Mumford's words, it has nevertheless held considerable power as an antipode to the evanescence of time. The Culture of Cities (New York: Harcourt, Brace, Jovanovich, 1938), 434.

69 I am thinking of projects such as Micha Ullman's memorial to the Nazi book burning on Bebelplatz in Berlin, or Maya Lin's Vietnam Memorial. See James Young "The CounterMonument: Memory against Itself in Germany Today," Critical Inquiry 18 (Winter 1992): 26796. See also the collection of essays on absence, ruins, and memory in the Polish case: Obecność/Brak/Ślady. Wspótcześni artyści o żydowskiej Warszawie. Presence/Absence/Trace. Contemporary Artists on Jewish Warsaw (Warsaw: POLIN Museum of the History of Polish Jews, 2016). 
pedagogical content housed in his building - that is, the museum's narration of German-Jewish history intrinsically contradicted his aspiration to perpetuate a memory oriented towards absence, ruination, and rupture. Despite the limitations each of these projects faced, they both challenge not only the forgetting of suffering in the postwar period but also the general propensity to turn away from the fragility and vulnerability of the human condition.

\begin{abstract}
This essay provides an interpretation of parallel attempts to represent ruination in the cities of Warsaw and Berlin after the Holocaust - the architectural projects of Bohdan Lachert and Daniel Libeskind. Lachert strove to represent the ruination of Jewish life in Warsaw through a modernist housing project, whereas Libeskind sought to represent Jewish ruination in a museum. While these two projects might seem different, they come together around a shared aspiration: to represent absence and ruination. Both projects endeavored to create a new kind of memorial that moved away from the conventional form. Rather than turning away from ruination and suffering as the conventional monument has done, Libeskind and Lachert sought to develop a new, non-salvific kind of monument that would reflect on death, suffering, and emptiness. This essay emphasizes the novelty of their attempts to create a different relationship to the absence that is the past, while it also explores some of the central challengesboth historical and theoretical - that both architects faced in implementing their artistic visions.
\end{abstract}

Key words: Daniel Libeskind, Bohdan Lachert, memory, salvation, ruins, postwar architecture 